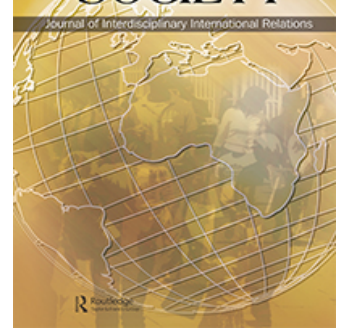

Global Society

\title{
Online Participation and the New Global Democracy: Avaaz, a Case Study
}

\section{Lanka Horstink}

To cite this article: Lanka Horstink (2017) Online Participation and the New Global Democracy: Avaaz, a Case Study, Global Society, 31:1, 101-124, DOI: 10.1080/13600826.2016.1235552

To link to this article: http://dx.doi.org/10.1080/13600826.2016.1235552

曲 Published online: 02 Dec 2016.

Submit your article to this journal $\asymp$

Џ Article views: 25

Q View related articles ¿

View Crossmark data ¿ 


\section{Online Participation and the New Global Democracy: Avaaz, a Case Study}

\section{LANKA HORSTINK}

More than 20 years after the Earth Summit of 1992, which introduced important social and ecological principles for policy-making and institutionalised participation, citizens are still largely excluded from decision-making processes that affect them. The internet was expected to change the balance of power in global politics. It has provided a platform for the presentation of alternative discourses and facilitated the organisation of social movements that clamour for a voice in global decision-making. The recent phenomenon of digital mobilisation has enthused the media, politicians, scholars and internet users alike. Could this be global democracy in the making? This article takes a critical look at the current dynamics of online participation, in particular the recent trend of online mass mobilisation, and will analyse the discourse, claims and practices of the web's largest movement, Avaaz, in an attempt to assess the democratic quality of an organisation that insists it is "people-powered" and "member-driven".

\section{Introduction}

While the rise of the internet has favoured the decentralisation of politics, offering affordable mass communication and mobilisation tools to minorities, social movements and even independent citizens, it has also brought the risk of populism, false consensus and disinformation. Besides traditional NGOs, interest groups and the aforementioned social movements, new and more obscure groups have also discovered the power and speed of internet politics. The objective of this article is to critically assess the democratic quality of online participation in what the author has termed "digital mass politics", by analysing the case of Avaaz, a non-profit organisation that sprung to fame by launching an online global petition site to influence policy-making at national and international levels. Avaaz was founded in 2006 by the leaders of Anglo-Saxon non-governmental organisations (NGOs) that were already pioneering web-based advocacy (among them MoveOn and GetUp!). The first of these web platforms to go global, Avaaz quickly took the lead in membership and revenue size. Membership soared to approximately 42 million in 2014, while revenues for the same year totalled US\$19.36 million, making Avaaz the most resourceful example of the "movement of public opinion"1 existing today.

1. Manuel Castells, "The New Public Sphere: Global Civil Society, Communication Networks, and Global Governance", The Annals of the American Academy of Political and Social Science, Vol. 616, No. 1 (2008), pp. 78-93. 
Avaaz and the organisations that helped found it can be considered hybrid forms of transnational activism, combining characteristics of the traditional advocacy organisations with those of second-generation network webs. The result is a new type of organisation that Chadwick calls "hybrid mobilization movements", 2 sometimes behaving like an interest group, sometimes like a social movement, and in the case of MoveOn, sometimes like the wing of a political party. Avaaz is closely modelled on the MoveOn example, which Karpf describes as an "Internetmediated issue generalist": organisations that have disruptively innovated political advocacy by redefining membership as linked to an online act (i.e. signing a petition) and revolutionising fundraising by pooling many small online donations in timely and targeted appeals. ${ }^{3}$ Karpf describes MoveOn's advocacy style as "headline chasing" - opportunistically appealing to action and/or donations according to the popularity of events in the news-and what he calls "issue grazing". ${ }^{4} \mathrm{He}$ concedes the undeniable success of these organisations in creating not just a new model of advocacy, but also new and nimble organisational practices and a new style of digitally savvy community organisers. ${ }^{5}$ Chadwick, however, warns against equating online activism with grassroots activism, arguing that what was considered mainstream is now adapting to the use of multiple media, while newer communication forms are becoming mainstream, prompting him to speak of "systemic hybridity". 6

As a recent phenomenon, online mass politics still lacks the empirical research to support the strong claims and counter-claims that have been made about it, such as that it strengthens democracy by increasing citizen participation or, on the contrary, that "interactivity is evil", serving to disarm resistance by giving online participants a sense of agency. ${ }^{7}$ This exploratory research aims to contribute to filling the relative void in research, building the analytical tools to guide further, more in-depth research. The author was interested in testing attributes of "substantive" democracy, understood as a qualitatively stronger form of democratic practice, as advocated by political thinkers such as Dewey, Rawls, Barber and Habermas. The notion that the current dominant form of liberal democracy - mostly representative and aggregative, favouring majority rule-is not enough by itself to guarantee all human, political and social rights has inspired a "deepening democracy" debate that explores theories of a more inclusive, participatory or deliberative democracy. ${ }^{8}$

Due to the critical mass that a self-proclaimed movement such as Avaaz can muster, and its success in capturing the attention of traditional media, coupled with the sensitivity of many of the issues that their petitions broach, the author

2. Andrew Chadwick, "Digital Network Repertoires and Organizational Hybridity", Political Communication, Vol. 24, No. 3 (2007), p. 284.

3. David Karpf, The MoveOn Effect: The Unexpected Transformation of American Political Advocacy (New York: Oxford University Press, 2012).

4. Ibid., p. 50.

5. Ibid., chapter 2.

6. Andrew Chadwick, The Hybrid Media System: Politics and Power (New York: Oxford University Press, 2013).

7. Kylie Jarrett, "Interactivity is Evil! A Critical Investigation of Web 2.0", First Monday, Vol. 13, No. 3 (2008), doi: 10.5210/fm.v13i3.2140.

8. John Gaventa, "Triumph, Deficit or Contestation? Deepening the 'Deepening Democracy' Debate", Working Paper 264 (Brighton: Institute of Development Studies, 2006). 
argues that their activities constitute an attempt at governance, therefore justifying the application of a deeper democratic framework.

The questions that guided the case study analysis were: What type of organisation is Avaaz: can it be considered an international NGO, a social movement or an interest group? How is the Avaaz community structured and governed? What is the democratic quality of the practices Avaaz employs and promotes? How substantive are the self-stated democratic purpose of Avaaz, the participation of its members and the democratic results of its campaigns?

This article is structured as follows. After providing a theoretical context for the phenomenon of mass digital politics, the author briefly presents the methodology of the case study and the framework for democratic quality that was used to critically assess Avaaz's mobilisation practices. The author will then present and discuss the results of the analysis for each of the democratic criteria.

\section{New Forms of Public Participation in Global Governance}

Governance and participation are both relatively recent terms and require some clarification. Bevir defines governance as the process of governing, but argues that in empirical terms nowadays it refers to "processes of rule wherever they occur". ${ }^{9}$ New actors and a variety of organisational forms have not only extended governance beyond governments' purview, but also transformed it into a desirable practice, to which contemporary frameworks for "good governance" ${ }^{10}$ can attest, offering guiding principles such as consensus-oriented public participation, strategic vision, accountability, transparency, responsiveness, effectiveness, efficiency, equitability and inclusiveness.

Participation is understood as "the process by which an organization consults with interested or affected individuals, organizations, and government entities before making a decision". ${ }^{11}$ Participation by non-state actors has become the norm, enshrined in international treaties such as the 1992 Rio Declaration and the European Commission's White Paper on Governance. ${ }^{12}$ Unfortunately, in practice, this participation of non-state actors in decision-making on issues of the common good has been found lacking in substance: used merely as an end in itself, ${ }^{13}$ not linked to practical outcomes, ${ }^{14}$ hampered by bias towards citizens'

9. Mark Bevir, Governance: A Very Short Introduction (Hampshire: Oxford University Press, 2012).

10. See, for example, John Graham, Bruce Amos and Timothy W. Plumptre, Governance Principles for Protected Areas in the 21st Century (Ottawa, Canada: Institute on Governance, 2003); UN governance guidelines, available: <http://www.ohchr.org/en/Issues/Development/GoodGovernance/Pages/Good GovernanceIndex.aspx> (accessed 20 June 2013).

11. "IAP2: Good Public Participation Results in Better Decisions", available: <http://www.iap2.org/> (accessed 6 December 2015).

12. EU Commission, "European Governance-A White Paper", COM (25 July 2001), available: $<$ http://europa.eu/rapid/press-release_DOC-01-10_en.htm> (accessed 30 June 2013).

13. Ulrike Felt and Maximilian Fochler, "The Bottom-Up Meanings of the Concept of Public Participation in Science and Technology", Science and Public Policy, Vol. 35, No. 7 (2008), pp. 489-499.

14. Alan Irwin, "Constructing the Scientific Citizen: Science and Democracy in the Biosciences", Public Understanding of Science, Vol. 10, No. 1 (2001), pp. 1-18. 
capacity for rational decision-making ${ }^{15}$ or simply resulting in decisions that are not binding. ${ }^{16}$

Whether despite or because of the disillusionment with formal public participation and the lack of results in global governance, uninvited forms of participation in policy-making have sprung up, changing the political landscape from easily identifiable and clearly delimited political actors to a myriad of amorphous organisations and movements that act across borders. According to Keane, ${ }^{17}$ we are currently living in monitory democracies in most parts of the world, embodied by special interest lobby groups, NGOs, public commissions and forums, think tanks, international covenants, earth watch organisations, bloggers, whistleblowers and legal class actions. The topography of politics has changed: political discourse, debate and judgement increasingly take place next to or across the institutions that traditionally hold political power. Faced with democratic and ecological deficits in the representative forms of democracy available to them, these new actors experiment with new forms of democracy.

Proponents of cosmopolitan democracy theories imagine that a global civil society or global democracy ${ }^{18}$ is in the making, with social and economic actors filling the void of representation and legitimate policy-making, ${ }^{19}$ reining in the power of supranational agencies and transnational corporations. Castells proposes four typologies to help understand the new dynamics: ${ }^{20}(1)$ the (older) local interest groups that continue to defend local interests and/or specific values; (2) the fairly recent international NGOs that have conquered a formal seat and a voice, if not a vote, at the negotiating tables for international agreements; (3) the social movements, calling upon global solidarity to survive and assert their rights, connecting local resistance groups in a network to counter the usurpation of democracy by powerful governments and corporate interests; and (4) the movement of public opinion, ${ }^{21}$ which has been facilitated by the spread of Information and Communication Technologies (ICTs). In Castells' definition, social movements are essentially democratic movements that call for "new forms of political representation of people's will and interests in the process of global governance", ${ }^{22}$ whereas movements of public opinion are "spontaneous, ad hoc mobilizations using horizontal, autonomous communications systems". ${ }^{23}$ Examples of this latter form of participation are the Acampada and Occupy movements, clamouring for "real" democracy, that spread across the globe in 2011. Within this typology, MoveOn and Avaaz and similar organisations represent a hybrid form of activism, combining second-generation characteristics, like those of Occupy, with traits of more

15. Claire Marris, Brian Wynne, Peter Simmons and Sue Weldon, Public Perceptions of Agricultural Biotechnologies in Europe (Lancaster, UK: Lancaster University, 2001).

16. Richard E. Sclove, Reinventing Technology Assessment: A $21^{\text {st }}$ Century Model (Washington, DC: Science and Technology Innovation Program, Woodrow Wilson International Center for Scholars, 2010).

17. John Keane, The Life and Death of Democracy (London: Simon and Schuster, 2009).

18. Daniele Archibugi, "Cosmopolitan Democracy and Its Critics: A Review", European Journal of International Relations, Vol. 10, No. 3 (2004), pp. 437-473.

19. Manuel Castells, "Global Governance and Global Politics", Political Science and Politics, Vol. 38, No. 1 (2005), pp. 9-16.

20. Castells, “The New Public Sphere", op. cit., pp. 83-86.

21. Ibid., p. 86.

22. Ibid., pp. 85-86.

23. Ibid., p. 86. 
traditional advocacy organisations (e.g. the centralisation of decision-making, the use of experts, and a strong focus on media value of the causes embraced).

\section{Public Participation on the Internet and Global Democracy}

In the 1990s the internet was seen as a facilitator for the participatory democracy that many believed was in the making, and scholars marvelled at its potential as an expanded public sphere where rational-critical citizen discourse could thrive. ${ }^{24}$ Since broadcasting centres are at the strategic core of political power, the internet and its possibilities for low-cost broadcasting to large numbers of other citizens (many-to-many) is a potential enabling factor for democracy, bypassing traditional power centres. ${ }^{25}$

Dahlgren observes that the various groups, networks, organisations and social movements that are engaged in global politics all make use of ICTs in some way or another. ${ }^{26}$ International NGOs are successfully using social media tools that allow for rapid sharing of text, sound, image and video in "bitesize" form to pressure governments and corporations. Governments themselves and their politicians use ICTs to personalise their messages and gauge public opinion. Social movements are using social media to mobilise, organise and publicise. Finally, new, exclusively digital-based organisations, like Change.org, Avaaz and 38 Degrees have created platforms that allow citizens to pressure both national and supranational governance institutions on a wide range of social, political and ecological issues. Their work falls under the category of online mobilisation, an independent form of online participation in which citizens try to influence public opinion and policy-making directly, either spontaneously or driven by an organisation or interest group. It contrasts with the more formal exponent of the online participation phenomenon, which has been dubbed e-democracy. Whereas for some scholars ${ }^{27}$ e-democracy is a complement to representative democracyusing ICTs to engage citizens and support democratic decision-making processes - for others, in particular deliberative democrats, it contains within it the possibilities of a genuine public sphere in the Habermasian sense. ${ }^{28}$

The nature and effectiveness of online participation and mobilisation has spurred a debate where extreme views collide (compare Castells ${ }^{29}$ enthusiasm to Morozov's $^{30}$ scepticism), and different approaches (social network analysis vs media analysis), as well as different foci (formal vs spontaneous e-participation initiatives), limit the drawing of conclusions. Some tendencies can however be identified.

24. Lincoln Dahlberg, "The Internet and Democratic Discourse: Exploring the Prospects of Online Deliberative Forums Extending the Public Sphere", Information, Communication \& Society, Vol. 4, No. 4 (2001), pp. 615-633.

25. Castells, "The New Public Sphere", op. cit., p. 90.

26. Peter Dahlgren, "Participation and Alternative Democracy: Social Media and Their Contingencies", in P. Serra, E. Camilo and G. Gonçalves (eds.), Participação Política e Web 2.0 (Covilhã: LabCom Books, 2013), pp. 57-82.

27. Ann Macintosh, "Characterizing E-participation in Policy-Making", in Proceedings of the 37th Hawaii International Conference on System Sciences (Washington, DC: Institute of Electrical and Electronics Engineers Computer Society, 2004), 10 pp.

28. Dahlberg, op. cit.

29. Manuel Castells, The Information Age. Volume Three: End of Millennium (Oxford: Blackwell, 1998).

30. Evgeny Morozov, "Whither Internet Control?" Journal of Democracy, Vol. 22, No. 2 (2011), pp. 62-74. 
An important empirical finding relates to the way internet users tend to polarise their judgements, either moderating or radicalising their view depending on whether the evidence challenges or supports them. According to Karpf, internet advocacy organisations will always tend to be polarised, because moderate views are not mobilising. ${ }^{31}$ Another repeated observation about online dynamics is the relative advantage of users with high social capital: not only do they account for most of the active contributions in online social networks, but they are also more likely to see increases in social capital through the use of these networks. ${ }^{32}$ And despite the fact that online participants do not merely overlap with offline participants (online participants tend to be younger), both groups nevertheless continue to share a predominance of the male gender and of higher socio-economic groups. ${ }^{33}$ Another study also showed that students are significantly more likely to use the internet for political purposes than unemployed youngsters. ${ }^{34}$ It seems the digital divide, despite the fact that the number of internet users reached the three billion mark in $2014,{ }^{35}$ still excludes not only most people from developing countries ( $75 \%$ of internet users are from the top 20 most connected countries), but also many people from economically disadvantaged backgrounds in developed countries.

Whether online participation can be considered effective or meaningful continues to be a subject of much debate, as is evident in Kavada's review. ${ }^{36}$ There is some evidence that, in general, politics on the net is "politics as usual"37 (the so-called normalisation theme), and that online discussions do not justify classifying the internet as a public sphere of inclusive, independent, rational-critical discourse. ${ }^{38}$ Gladwell argues that online participation builds only weak ties between action participants, not enough to actually take them to the streets. ${ }^{39}$ Morozov criticises the phenomenon of the "slacktivist": the internet user that clicks to like, share or approve without discussion, what he calls "feel-good online activism that has zero political or social impact". ${ }^{40}$

31. Karpf, op. cit., p. 10.

32. Barry Wellman, Anabel Quan Haase, James Witte and Keith Hampton, "Does the Internet Increase, Decrease, or Supplement Social Capital? Social Networks, Participation, and Community Commitment", American Behavioral Scientist, Vol. 45, No. 3 (2001), pp. 437-456.

33. Jennifer Oser, Marc Hooghe and Sofie Marien, "Is Online Participation Distinct from Offline Participation? A Latent Class Analysis of Participation Types and Their Stratification", Political Research Quarterly, Vol. 66, No. 1 (2013), pp. 91-101.

34. Rachel Gibson and Marta Cantijoch, "Conceptualizing and Measuring Participation in the Age of the Internet: Is Online Political Engagement Really Different to Offline?", The Journal of Politics, Vol. 75, No. 3 (2013), pp. 701-716.

35. Internet Live Stats, available: <http://www.internetlivestats.com/internet-users/> (accessed 15 October 2015).

36. Anastasia Kavada, "Engagement, Bonding, and Identity across Multiple Platforms: Avaaz on Facebook, YouTube, and MySpace", MedieKultur: Journal of Media and Communication Research, Vol. 52 (2012), pp. 28-48.

37. Michael Margolis and David Resnick, Politics as Usual: The Cyberspace "Revolution" (London: Sage, 2000); Pippa Norris, Digital Divide: Civic Engagement, Information Poverty, and the Internet Worldwide (Cambridge: Cambridge University Press, 2001).

38. Dahlberg, op. cit.; Andrew Chadwick, "Web 2.0: New Challenges for the Study of E-democracy in an Era of Informational Exuberance", Journal of Law and Policy for the Information Society, Vol. 5 (2008), pp. 9-42.

39. Malcolm Gladwell, "Small Change: Why the Revolution Will Not Be Tweeted", The New Yorker, Vol. 4 (2010), pp. 42-49.

40. Evgeny Morozov, "The Brave New World of Slacktivism", Foreign Policy (May 2009), available: <http://www.npr.org/templates/story/story.php?storyId=104302141> (accessed 10 June 2013). 
More nuanced views, such as Gerbaudo's, find some "valuable attempts to reinvent democracy" but also several risks, such as the disregard for minority views, authoritarian tendencies and what he calls "techno-plebiscitarianism" (equivalent to de Tocqueville's "tyranny of the majority") and "techno-proceduralism" (an "obsession with web procedures and tools"). ${ }^{41}$ Gerbaudo believes that mass logics of communication have returned to the internet, where just one social network site, Facebook, has over a billion users, and communication tools have become homogenised, pointing to a possible loss in the autonomy and diversity that the internet was initially heralded for. He identifies a new form of populism practised by online political organisers, where the average internet user becomes the new "common man" at whom appeals are launched to go beyond his or her "individualised condition and to use their connectivity as a springboard to join a collective mobilisation". ${ }^{42}$

Karpf and Chadwick also offer a third way for assessing the impact of ICTs on collective action, by presenting evidence that the use of digital communication technologies is creating a hybrid form of mobilisation that has revolutionised the concept of membership and the tactics for fundraising, which have both become flexible and fluid. ${ }^{43}$ Organisational hybrids such as MoveOn, Get Up!, 38 Degrees and Avaaz switch between repertoires (a "limited set of routines" ${ }^{44}$ ) and between media with hereto unseen organisational flexibility, using online media for "tight feedback loops, coordination, more active engagement, and representing the movement to itself", and traditional media as a sign of "its efficacy for wider publics", ${ }^{45}$ while sometimes complementing communication with staged protest events.

Chadwick has observed that for these organisations, speed is of the highest essence. ${ }^{46}$ The use of real-time response is more than a communication tactic; it is a strategy to generate the authenticity and legitimacy needed to keep supporters engaged. Studying the online advocacy group 38 Degrees, Chadwick finds that these type of organisations blend long-term planning with "nimble" responses as events unfold, or as one of the leaders he interviewed put it, "being opportunistic within a strategic framework". ${ }^{47}$

Recent research shows that we must be careful to apply labels to the new internet-enabled organisations and movements. Whereas he considered MoveOn, from whence Avaaz stems, a "top-down manufactured community", Chadwick encountered in 38 Degrees a mixture of leadership and incorporation of supporters' wishes through the monitoring of social media sites, blog posts, online polls and petitions. "Hestres found the organisation 350.org to be a "headline generator"

41. Paolo Gerbaudo, "Populism 2.0: Social Media Activism, the Generic Internet User and Interactive Direct Democracy", in D. Trottier and C. Fuchs (eds.), Social Media, Politics and the State: Protests, Revolutions, Riots, Crime and Policing in the Age of Facebook, Twitter and YouTube (New York and Oxon: Routledge, 2014), pp. 67-87.

42. Ibid., p. 79.

43. Karpf, op. cit.; Chadwick, The Hybrid Media System, op. cit.

44. Chadwick, “Digital Network Repertoires”, op. cit., p. 285.

45. Chadwick, The Hybrid Media System, op. cit., p. 193.

46. Ibid.

47. Ibid., p. 192.

48. Andrew Chadwick and James Dennis, "Social Media, Professional Media and Mobilisation in Contemporary Britain: Explaining the Strengths and Weaknesses of the Citizens' Movement 38 Degrees", Political Studies, online first (May 2016), doi: 10.1177/0032321716631350. 
rather than chaser, ${ }^{49}$ reaching out to people who are already alarmed by climate change and to whom they offer online as well as offline actions, empowering local organisers with campaigning tools. These studies also show that organisational capacity and leadership are important variables in most of the current political mobilisations on the internet, contradicting the initial conclusions pointing at "organizing without organizations". 50

\section{Methodology}

The data collected for this case study include self-presentations by Avaaz's managing team (either on their website or in public interviews), historical and documental data on the organisation, Avaaz's communication tools, self-descriptions of their campaigns, communications within the Avaaz community, reports by external parties and other researchers, news reports on the campaigns, and data available on the context of these campaigns. Most of the data were collected online between May and June 2013, with some data complemented in 2014 and 2015. As much as space allows, data sources are referred to in the text. The author had access to email communications between Avaaz and its members since 2007, the year of its inception, having signed up at this time.

Data from the website were analysed using features analysis, used by Foot and Schneider to analyse the role of websites in US election campaigns. ${ }^{51}$ Features analysis is a form of web content analysis that records the occurrence of available features for interaction and participation on a website.

This was complemented by an exploratory form of critical discourse analysis, ${ }^{52}$ where discourse is understood as a particular way of representing aspects of social life, including aspects that are desired or possible worlds. Discourses reveal the social practices (more or less stable and durable forms of social activity) and thus the social structures to which the discursants adhere, revealing relations of power and dominance in society. The author was interested in the social structures that inform Avaaz's practices, which can be found in their use of valueladen concepts such as democracy, participation, economy and freedom, in their explanation of the events that they campaign on and in the strategies they promote.

Avaaz's observable practices were first classified according to the features on their website and social media pages that are available for interaction with members, such as mission statements, "take action" features, campaign highlights, campaign information, press releases and counters or tickers.

These features of interaction, together with the content and form of Avaaz's communications (email communications being their primary tool), were then compared to the criteria for substantive democracy distilled for the purpose of a previous case study analysing the Rio+20 discourses. ${ }^{53}$ These categories were compiled from a list

49. Luis Hestres, "Preaching to the Choir: Internet-Mediated Advocacy, Issue Public Mobilization, and Climate Change", New Media Society, Vol. 16, No. 2 (2014), pp. 323-339.

50. Chadwick and Dennis, op. cit., p. 24.

51. Kirsten A. Foot and Steven M. Schneider, Web Campaigning (Cambridge, MA and London: The MIT Press, 2006).

52. Norman Fairclough, "Critical Discourse Analysis as a Method in Social Scientific Research", in R. Wodak and M. Meyer (eds.), Introducing Qualitative Methods: Methods of Critical Discourse Analysis (London: Sage Publications, 2001), pp. 121-138.

53. Lanka Horstink, "Es sostenible si es comercializable: la brecha democrática y ecológica en el discurso del desarrollismo verde", Ecologia Política, No. 44 (2013), pp. 15-20. 
of workable attributes of deep democracy, based on the reflections of proponents of deliberative, deep and radical democracy, in particular theories of ecological democracy. Their selection was motivated by a quest for democratic quality, understood as an ideal democratic practice that, at a time when humanity faces enormous social-ecological challenges, embraces notions of social and environmental justice, deemed by many of the deep democrats to repair the shortcomings of a liberal democracy that is more focused on the protection of civil rights than on the development of true equality and freedom. Since Avaaz campaigns on issues of social and environmental justice, an ecological democratic framework to analyse their practices appears as the logical choice. For the purpose of this case study, the criteria of "guaranteeing equity", "autonomy or control over resources" (a stronger version of freedom) and "capacity for altruism" were not considered, as they relate more specifically to the governance of resources. Also, to be able to compare between "basic" and "stronger" democratic criteria, the author decided to add four basic democratic dimensions, which are usually not contested among democratic theorists. Below follows a list of criteria used and a brief explanation for their inclusion.

1. Basic democratic dimensions (what most democratic theorists agree on in the context of public participation, based on Ostling, ${ }^{54}$ who adapted these attributes to e-democracy contexts):

i. equality (participation without domination of any group's interests and without discrimination on the basis of factors such as gender, age, ethnicity or socio-economic group);

ii. freedom (transparent and accountable moderation-including the features available for people to participate and how accessible these areand respect for privacy);

iii. transparency/accountability (balanced and comprehensible presentation of the information informing policies, and of the process and results);

iv. responsiveness (the participants' influence on the topics discussed on the platform in question (responsiveness of Avaaz) and their ultimate influence on policy agendas and policies of the targeted governing agencies (responsiveness of Avaaz's actions);

2. Active equitable inclusion: a stronger version of equality, seeking to include and empower all interested parties in the decision-making process. Based on Habermas's conditions for the public sphere; ${ }^{55}$

3. Social legitimacy: can be construed as a strong version of accountability or democratic legitimacy when those who bear the consequences of decisions by others have a final say in decision-making, ${ }^{56}$

54. Alina Ostling, "How Democratic is E-participation?", in Proceedings of the International Conference for E-Democracy and Open Government (Krems, Austria: Edition Donau-Universität Krems, 2011), pp. 59-70.

55. Jurgen Habermas, The Structural Transformation of the Public Sphere: An Inquiry into a Category of Bourgeois Society (Cambridge, MA: MIT Press, 1991).

56. Deliberative democrats prefer the term "democratic legitimacy", whereas social legitimacy has been used more often in legal contexts. The latter term is, however, closer to Habermas's idea of legitimacy as requiring the consent of all those to whom decisions or laws will apply. 
4. The use of deliberation: converging on common interests through the advancement of rational-critical arguments. ${ }^{57}$ In the deliberative democracy tradition, which has solidified considerably in the last decades, the debates are expected to take place in terms of conceptions of the common good as opposed to bargaining for particular interests. The more deliberative forms of participatory processes tend to score higher on broad quality criteria (such as joint gains, added information and innovative ideas) than less intensive stakeholder processes. ${ }^{58}$ Most deliberative democrats believe the deliberative procedure to be the main source of legitimacy;

5. Reflexivity: an attitude of collective self-awareness, self-inquiry and self-confrontation that is deemed a necessary condition to break with path dependency in decision-making and for social learning in democratic practices to occur; ${ }^{59}$

6. Cognitive justice: the constitutional right of different systems of knowledge to exist as part of a dialogue and debate, thereby strengthening the participation of lesser-recognised groups with cognitive representation, democratising knowledge itself. ${ }^{60}$

When appropriate and possible, data were analysed by cross-checking presented facts. Sources of claims and counter-claims are presented along the analysis where space allows.

\section{A Case Study for the "New Global Democracy": Avaaz}

In the next sections, Avaaz's governance of the community it created and its public campaigning activities will be analysed according to each of the attributes for democratic quality defined in the methodology section.

\section{Avaaz and Basic Democratic Dimensions}

\section{Equality}

The research revealed several obstacles to equality in Avaaz's community, among them the risk of domination of specific group interests over others and a bias towards higher socio-economic groups. Firstly, several relatively powerful groups have been identified by the author as part of the executive and wider support structure of Avaaz, among them MoveOn, GetUp! and a foundation of the billionaire George Soros, who funded Avaaz at the start-up. ${ }^{61}$ Their founders, including those of Avaaz, are usually active in more than one digital movement, self-

57. Joshua Cohen, "Deliberation and Democratic Legitimacy", in J. Bohman and W. Rehg (eds.), Deliberative Democracy: Essays on Reason and Politics (Cambridge, MA: MIT Press, 1997), pp. 67-91.

58. See, among others, Michel Pimbert and Tom Wakeford, "Prajateerpu, Power and Knowledge: The Politics of Participatory Action Research in Development Part 1. Context, Process and Safeguards", Action Research, Vol. 1, No. 2 (2003), pp. 184-207.

59. Jan-Peter Voss and Dierk Bauknecht (eds.), Reflexive Governance for Sustainable Development (Cheltenham, UK; Northampton, MA: Edward Elgar Publishing, 2006).

60. Shiv Visvanathan, "Knowledge, Justice and Democracy", in M. Leach, I. Scoones and B. Wynne (eds.), Science and Citizens (London: Zed Books, 2005), pp. 83-94.

61. Tax returns for the Open Society Institute in 2008 and the Foundation to Promote Open Society in 2009, the latter published by the NGO watchdog Guidestar, with endowments for Avaaz of respectively US\$250,000 and 600,000 through Res Publica, available: <http://990s.foundationcenter.org/990pf_pdf_ archive/137/137029285/137029285_200812_990PF.pdf> and <http://www.guidestar.org/FinDocuments/ 2009/263/753/2009-263753801-068647db-F.pdf> (accessed 20 October 2013). 
describing their profession as creating "new organizations and ventures to tackle issues where mass participation and collective action can unlock big change" ${ }^{.62}$

Secondly, the available features for participants' involvement in Avaaz's activities as listed in Table 1 are limited to signing one of six petitions (as a rule Avaaz never places more than six campaigns at a time on their website), donating, joining for email alerts and either writing a short story about what Avaaz means to them or approving ("heart-ing") someone else's story.

Those who visit the yearly poll may also leave a message there, similar to a Facebook wall message. On Avaaz's social media pages, users of these networks can leave (moderated) comments. A more interactive feature, which Avaaz started offering a few years after their launch, is the possibility of subscribers launching their own petitions. There is, however, no guarantee that Avaaz will share this petition with the other subscribers. Furthermore, although Avaaz offers a choice of 15 languages, the social media content is overwhelmingly in English. On the whole, communication is restricted to one-to-many and many-to-one: Avaaz communicates with its subscribers and subscribers leave messages that are overwhelmingly directed at Avaaz, offering "solidarity, thanks, and congratulations". ${ }^{63}$

Avaaz has no general assembly, instead, like a company, it has an appointed executive board. ${ }^{64}$ There is no mechanism for outside groups or members to influence Avaaz's governance. Like other digitally networked NGOs, Avaaz uses A/B (split) testing of campaigns on samples of subscribers, but this is not the same as co-deciding campaign priorities, since it has already been decided what will be tested. Avaaz started conducting yearly polls in 2013, where supporters rate priorities and campaign ideas, and rate Avaaz. ${ }^{65}$ The phrasing of the priorities and campaign choices can be considered broad, both in wording ("Every Child in Schoolwork to get funding and political action so that the children that are still out of school, many because of wars or natural disasters, get an education") and as a whole (from combatting slavery and violence towards women, to "saving the Amazon" and elephants, or obtaining peace in Syria). At the same time, the choices direct users towards one strategy rather than another (for example when Avaaz asks users to campaign to end the grip of the corporation Monsanto on the food system) and some priorities are extremely specific, such as the demand for peace in Syria at a time when civil war is raging in many other countriesincluding neighbouring countries Afghanistan and Iraq-or the call to "Cleanout US corruption", specifically linked to the upcoming elections.

Avaaz's membership functions through self-selection, which as a democratic mechanism has already been found defective, since it tends to reinforce existing dominant groups. ${ }^{66}$ Looking at the profile of the Avaaz community, which has recently become available with the yearly polls, we can observe that subscribers are becoming younger: whereas nearly 63\% were parents in 2014, in 2016 this

62. Purpose.com, launched by an Avaaz co-founder, available: $<$ http://www.purpose.com/ $>$ (accessed 16 June 2013). On the site we can read: "We build movements" (...) "from the ground up".

63. Kavada, "Engagement, Bonding, and Identity", op. cit.

64. The decision structure is briefly presented in Avaaz's financial statements, available: <http://www. avaaz.org/en/avaaz_expenses_and_financial_information/> (accessed 21 October 2013).

65. Avaaz yearly poll 2016, available: <https://secure.avaaz.org/en/poll_results_2016/> (accessed 25 May 2016).

66. Archon Fung, "Varieties of Participation in Complex Governance", Public Administration Review, Vol. 66, Special Issue (2006), pp. 66-75. 
Table 1. Features Analysis of the Tools for Interaction Used by Avaaz.

\begin{tabular}{|c|c|c|c|}
\hline Features for interaction & Avaaz website & Email alert list & $\begin{array}{c}\text { Other webpages } \\
\text { (Facebook, YouTube etc.) }\end{array}$ \\
\hline Features readily available & $\begin{array}{l}\text { > Homepage with } 6 \text { main campaigns; } \\
\text { campaigns have short texts and occasionally } \\
\text { a video } \\
>\text { Slogan } \\
>\text { About Us } \\
>\text { Selected testimonies from public figures and } \\
\text { from Avaaz "members" } \\
>\text { Stories of Us } \\
>\text { Start your Own Petition } \\
>\text { Ticker of number of "members" } \\
>\text { Ticker of recent signatures "Happening right } \\
\text { now" } \\
>\text { Campaign highlights } \\
>\text { Media centre } \\
>\text { Donate buttons } \\
>\text { Act now buttons (repeated on average } 12 \\
\text { times on homepage) } \\
>\text { Connect with Avaaz on FB and Twitter or } \\
\text { "Like" Avaaz } \\
>\text { Avaaz By the Numbers: tickers for number of } \\
\text { members, actions taken and countries } \\
>\text { Statement on Commitment to Accuracy }\end{array}$ & $\begin{array}{l}\text { Links to additional } \\
\text { information } \\
\text { Link to sign the petition } \\
\text { Link to donate } \\
\text { Link to "share with } \\
\text { friends" (after } \\
\text { signing) }\end{array}$ & $\begin{array}{l}>\text { Mission } \\
>\text { Status update } \\
>\text { Slogan } \\
>\text { Date founded } \\
>\text { Website URL } \\
>\text { Links to other networking and } \\
\text { Content-sharing sites } \\
>\text { Comments } \\
>\text { Videos and photos } \\
>\text { List of main followers, among them } \\
\quad \text { MoveOn.org, GetUp! and 350.org }\end{array}$ \\
\hline
\end{tabular}


Secondary features and features "buried" in the webpages

\section{What visitors can do}

$>$ Contact Avaaz

$>$ Privacy Policy and Terms of Use

$>$ Access to latest poll

$>$ Access to Forum for latest poll (only accessible on poll page)

$>$ Financial reports

$>$ Daily briefing (not accessible from the website and discontinued)

$>$ Act now - signing petitions (automatically counted as a member)

$>$ Donate

$>$ Start their own petition

$>$ Join for email alerts (automatically counted as a member)

$>$ Write a "Story of Us" (moderated by Avaaz)

$>$ "Heart" other Stories of Us

$>$ Leave a comment (only available for those who visit the poll and moderated)

\section{$>$ Read supporting} information

$>$ Sign petition

$>$ Donate

$>$ Forward to friends
$>$ "Like" Avaaz

$>$ "Like" individual posts

$>$ Comment on posts (moderated)

$>$ Watch videos and photos

$>$ Accept invitations to attend Avaaz events

$>$ See who else is a "friend" of Avaaz

$>$ Forward/share

$>$ Receive RSS feeds of updates 
dropped to $49 \%$. The tendency for Avaaz supporters to come from an educational or university background has also diminished from around 20\% in 2014 to just under $16 \%$ in 2016. But members still predominate in Anglo-Saxon, European and BRICS countries, with over 3 million from North America, close to 20 million from Europe and a staggering 10 million from Brazil. Nevertheless, Mexico has over 1.3 million subscribers. China and the ex-USSR have low participation, with the exception of Russia. African and East Asian countries are barely represented, with the exception of South Africa and some North African countries.

Although more research would be needed to detail exactly how Avaaz decides on campaign priorities, the information presented above on the structure of the organisation and its team, the profile of subscribers and the limited participation allowed them, indicates a substantial risk for the domination of an elite group's interests, undermining equality.

\section{Freedom}

Freedom in online participation settings depends mostly on the transparency and accountability of moderation and the features available for participation. Avaaz's community members, as we have seen, are not completely free to express their views, there being no platform for discussion, only a few moderated spaces for leaving comments, for which they need to be a member of a social media site. On the website, subscribers may only leave short stories of who they are and why they joined Avaaz, which other subscribers may then approve. Supporters also cannot communicate among themselves, but need to direct their comments at Avaaz.

Avaaz operates an opt-out model, meaning that people who sign up for their email alerts or sign their petitions are automatically counted as a member, unless they explicitly object. The opt-out model is legal, but lacks transparency; it would be more straightforward to ask people if they wish to join Avaaz. It is unclear if any of the subscribers have opted out or how many of the over 40 million subscribers are still active. Just as there is no official way of joining the movement, there is none for leaving. Also, although Avaaz does give a guarantee of privacy of personal data to participants, in return they demand that all content provided by members (including petitions started by members) becomes the property of Avaaz.

Overall, as revealed by the features analysis, participants of Avaaz have very limited choices both for communication and for action available to them. Of all the online advocacy organisations, Avaaz is the one with the least interactive features (MoveOn offers comments on its site and several choices of online and offline actions). Avaaz's executive director, Ricken Patel, has in numerous interviews stated that Avaaz purposefully chose a more centralised model, where, despite regular feedback surveys, "priorities and methods of the organisation are actually determined by a fairly small group of decision-makers" ${ }^{67}$ The general argument presented by Avaaz senior staff is that there is a difference between becoming involved and wanting to be empowered in deciding what the group does. This interpretation of supporters' wishes gives Avaaz a rather broad mandate.

67. Molly Beutz Land, "Networked Activism", Harvard Human Rights Journal, Vol. 22 (2009), pp. 205243. 
However, this is a dilemma that the traditional NGOs also face: the trade-off between participation and the need to maintain an image of unity and coherence to allow for broad mobilisation. There is a fear that online interaction may expose fractures within the group or network. ${ }^{68}$ Additionally, it may be argued that the internet provides these participants with alternative forums, if they wish, by starting their own social media groups. But for several reasons we should expect a more careful governance: this is the largest online community and the issues that are promoted may interfere with the sovereignty of countries outside of the promoter's purview. It would be sad, and potentially dangerous, if Avaaz only used its numbers to put critical mass behind the issues it wishes to promote.

\section{Transparency/accountability}

Of the democratic quality dimensions defined by the author, this is the one with the most evidence to support a negative conclusion. To begin with, Avaaz supplies no specific information on how their organisation or the community they have created is being governed. There is no information on the statutes of the organisation, or on the team behind Avaaz, let alone information on the principles to guide the "community", the process of decision-making or how results are evaluated. The tax forms that Avaaz started publishing in 2012 present very broad categories for revenues and expenses, making it impossible to verify the sources or destinations of Avaaz's money. For example, there is no evidence to support the claims of millions of US dollars given to Burmese monks. Some information, like those identifying donors of larger sums, has been redacted before publication. There are no yearly activity reports, nor does Avaaz publish campaign reports. In the Highlights section a selection of allegedly successful campaigns is presented with very short descriptions that do not allow for independent verification of the claims of victory or explain how money was spent. Many of the campaigns do not link back to the original appeal and there is evidence that unsuccessful, less successful, or controversial campaigns disappear from the website. ${ }^{69}$

Although keeping information on a need-to-know level can be comprehensible for an organisation that mass communicates with millions of people, from a perspective of social responsibility, more information should be available for those requesting it. Considering that Avaaz receives considerable donations from its subscribers, and not only claims it is $100 \%$ member-funded but also calls its members its "bosses", 70 it follows that as stakeholders in an organisation, members should be entitled to know how the money is spent. Instead there are no follow-ups on specific, generally urgent donation requests made by Avaaz and that involve considerable sums of money: rough estimates from the respective petition pages show

68. Scott Wright and Stephen Coleman, "The Third Sector as E-democratic Intermediaries", in S. Coleman and P.M. Shane (eds.), Connecting Democracy: Online Consultation and the Flow of Political Communication (Cambridge, MA: The MIT Press, 2012), pp. 209-228.

69. To give an example of this practice, the much criticised militaristic appeal by Avaaz for a no-fly zone in Libya <https://secure.avaaz.org/en/libya_no_fly_zone_1/?rc=fb> has been rephrased as "lives saved in Libya" through "asset freezes and protective action" and the information about how many people signed the appeal for a no-fly zone has been removed from the (now orphaned) page.

70. James Ball, "Avaaz: Can Online Campaigning Reinvent Politics", The Guardian, 15 January 2013, available: <http://www.guardian.co.uk/world/2013/jan/15/avaaz-online-campaigning-reinvent-politics> (accessed 21 May 2013). 
Avaaz collected approximately $€ 250,000$ to “break Monsanto's grip on our politics and our food" (no action plan was offered). ${ }^{71}$ They also may have collected as much as $€ 300,000$ to help create a "global opinion poll in dozens of countries that clearly shows this is not a fringe movement ${ }^{\prime \prime}{ }^{72}$ There is no evidence whatsoever that the afore-mentioned projects ever saw the light of day. Avaaz has never campaigned against Monsanto, although it has used the name repeatedly to ask for donations. ${ }^{73}$ These campaigns and requests have disappeared from Avaaz's self-reported history on the Highlights page and all page links eliminated.

Avaaz, as do other advocacy organisations when using the internet, uses persuasive language and the occasional poignant photograph to help galvanise its supporters and push through messages in very short time periods. The wording in emails, their main tool, is invariably dramatic and always urgent, ${ }^{74}$ asking members to "act now" or "donate now". Information given is very brief, focusing on one main reason why subscribers should help, and providing some links to newspaper articles for context. A communication tactic frequently used by Avaaz is to mention unnamed expert advisors ${ }^{75}$ to legitimise their requests to support a cause, potentially providing Avaaz with deniability if the information does not pan out. The asks of petitions are usually multiple, potentially providing more opportunities to claim victory, as in the Whale campaign: "prohibit the transit of whale meat through Dutch ports and help end the global trade in whales"76 (emphasis added).

Avaaz's directors self-describe their campaigning style as obeying a formula of "crisistunity": ${ }^{77}$ to spur people to sign or donate, a time frame for action is set (usually a few days, sometimes hours), with an initial objective (which can be adjusted if success allows), and a description of a situation that is always as much a crisis as it is an opportunity. The crisis is usually presented in the title and in the first line, whereas the opportunity (to sign or donate to "make a difference") follows straight after.

From the emails the author received between 2008 and 2013, Avaaz is estimated to have initiated about 60 campaigns in this time period. To find a history of these campaigns, however, the author had to use internet search engines because the Avaaz site does not have a search function. Avaaz does not even list all ongoing petitions but limits the offer to six rotating campaigns promoted on their homepage.

71. Avaaz, "Break Monsanto's Grip" (April 2013), available: <https://secure.avaaz.org/en/stop_ monsanto_nddon/> (accessed 30 June 2013).

72. Avaaz, "The $99 \%$ Speak Out" (2011), previously available: $<$ https://secure.avaaz.org/en/fund_the_ 99_poll/> (accessed 30 June 2013). This appeal was removed some time after the author accessed it; remnants of its existence can be found on other sites: <http://goldenageofgaia.com/2011/11/25/avaaz-plansglobal-opinion-poll/> (accessed 2 November 2016).

73. In this example, Avaaz asks for money for an unspecified seed bank, available: <https://secure. avaaz.org/en/seed_exchange_donate_loc/?pv=667\&rc=fb> (accessed 10 May 2016).

74. For examples of wording, click on each of the campaigns promoted on the homepage, available: $<$ https://www.avaaz.org/en/index.php> (accessed 12 May 2016).

75. Avaaz, "Europe: Lead on Efficiency" (2013), available: <http://www.avaaz.org/en/refrigerator_ revolution_video/> (accessed 2 November 2013); Avaaz, "US Government: Fast-Track African Lions as Endangered!" (2015), available: <https://secure.avaaz.org/en/us_list_endangered_african_lions/?pv= $77 \& \mathrm{rc}=\mathrm{fb}>$ (accessed 20 December 2015).

76. Avaaz, "Days to Stop the Whale Massacre" (2013), available: <http://www.avaaz.org/en/days_to_ stop_the_whale_slaughter_global/> (accessed 28 June 2013).

77. Ball, op. cit. 
The opt-out model and very fluid interpretation of membership, as seen under Freedom, contributes to an image of opaque practices. And as seen previously, website visitors have little information to go by and are restricted in their mobility. Unlike traditional activist NGOs, and despite the fact that Avaaz claims to have offices on six continents and a total staff of about 100, it is made difficult for members to contact Avaaz: the contact page is structured like that of any other online service organisation, with FAQs and an online form. No contact details are provided.

The yearly poll, the one opportunity for Avaaz members to pitch their vote, lacks information on how many people participated. If people made open suggestions, these have not been presented.

There are complaints that Avaaz has hooked onto successful campaigns in other countries, moving those campaigns to their own site. The fact that the Avaaz petition on the Ficha Limpa, Brazil's anti-corruption law, does not provide the usual ticker for signatories, and the fact that in Brazil a citizen's initiative is only valid with real signatures and by providing proof of identity, lends some credence to complaints that Avaaz took over a 1.6 million signature campaign already running in Brazil. Newspaper articles show that the petition was presented to Congress in September 2009, about seven months before Avaaz got involved. ${ }^{78}$

\section{Responsiveness}

Avaaz as an organisation has proven to be able to get many of the topics they push onto political agendas and media bulletins all over the world, by their sheer speed fomenting an attitude that values acting over talking. Their more successful petitions are usually accompanied by an advertising campaign in the country in question, which considerably raises awareness of the issue. As such, the responsiveness of their actions in terms of media impact can be considered high. But when an organisation claims its democratic mission is to "organize citizens of all nations to close the gap between the world we have and the world most people everywhere want" (About Us section), any result can be framed as a success. It was not possible in the short time frame of this study to assess actual impacts, but there are indications that Avaaz is not upfront about campaign results, either by exaggerating their role (as in the Ficha Limpa case and, more recently, the protest against glyphosate, which mobilised almost all advocacy organisations in this field in Europe ${ }^{79}$ ) or by disappearing less successful campaigns.

Looking at the degree of influence supporters are having on topics, agendas and policies, i.e. the responsiveness of Avaaz towards its members, the record is less favourable. Avaaz has final say over the campaigns it runs and publishes limited information on ongoing or past campaigns, or on any of its activities. As discussed previously, campaign priorities and goals are usually phrased in very broad terms, lacking clear strategies and action plans. The asks are framed in a way that is hard

78. Avaaz claims victory after Congress approves the law, available: <https://secure.avaaz.org/po/ brasil_ficha_limpa/?pv=9\&rc=fb>. English claim, available: <https://www.avaaz.org/en/vitoria_ficha_ limpa/>. Proof that the petition was handed to Congress in September 2009, available: <http://g1. globo.com/politica/noticia/2010/05/camara-conclui-votacao-e-projeto-ficha-limpa-vai-ao-senado.html> (accessed 30 June 2013).

79. Avaaz, "Protect our Health, Stop Monsanto" (March 2016), available: <https://secure.avaaz.org/ en/monsanto_dont_silence_science_loc/> (accessed 11 May 2016). 
to disagree with at first glance, while at the same time their realisation will be impossible to verify ("War on Women-Campaign to tackle the culture of violence towards women and win reforms to end oppression and give women the power to shape their own destinies" - 2016 poll).

Despite its claim of being fully "member-driven" and having members as their "bosses", and despite having marketed the yearly polls as "the biggest exercise in direct democracy ever undertaken", 80 Avaaz follows its own agenda. When comparing the priorities that came out of the polls of 2014 and 2015 with the campaigns actually launched, the correspondence is weak: the repeatedly promised campaigns on protecting the oceans, combatting Monsanto, ending modern slavery and putting every child in school were not undertaken in 2014 nor 2015, without explanation and even though money was collected for some of these campaigns. ${ }^{81}$

This unresponsiveness is not exclusive to Avaaz or online advocacy groups. Traditional advocacy groups, as Beutz Land found in her research, despite being considered representatives of the public interest, have also been called "decidedly un-democratic and unaccountable to the people they claim to represent". ${ }^{82}$ It is a common problem that plagues activism and largely has to do with the trade-off discussed earlier, between meaningful participation and larger mobilisation. Beutz Land claims the risk is partially offset by the professionalisation of these NGOs, but nevertheless improvements are needed. The fact that Avaaz is not a specialist NGO compounds the risk of the lack of responsiveness to its constituencies.

\section{Avaaz and Active Equitable Inclusion}

The only governance structure known for Avaaz is their four-member board as disclosed in their tax statements, and a host of unnamed experts and partners. There is no general assembly, forum or discussion list, and the definition of membership is very loose.

The problem of failing to include and empower all interested parties in the decision-making processes is again not exclusive to Avaaz, but typical of any group that claims to act on behalf of larger publics. Contacting stakeholders is a painstaking process that impedes swift campaigns, which explains why many advocacy groups prefer to partner with similar groups they may know and that are already on the ground in a region, to the detriment of local groups.

But unlike other activist organisations, including digital NGOs such as the climate campaign group 350.org, Avaaz does not attempt to decentralise campaigning by sharing the strategies of its successful campaigns or suggesting tools for activism other than the petition. As Kavada observes, Avaaz's purpose is "designed as a form of activism for busy people with few minutes to spare, Avaaz also demands little commitment from its members and makes it difficult to build a sense of community". ${ }^{83}$ This lack of real empowerment diminishes opportunities for individuals who are new to activism to take the step to get involved.

80. Ball, op. cit.

81. Poll results for 2014 and 2015, available: <https://secure.avaaz.org/en/poll_results_2014/>; <https:// secure.avaaz.org/en/poll_results_2015/?pv=709\&rc=fb> (accessed 20 May 2013).

82. Beutz Land, op. cit., p. 212.

83. Kavada, "Engagement, Bonding, and Identity", op. cit., p. 52. 
As mentioned earlier, most supporters are from wealthier countries and in the statistics in the 2016 poll we find the overwhelming majority has had a secondary education, with at least half having completed higher education, pointing to a selfselection of middle and upper middle class internet users. The combination of the profiles of Avaaz members with the top-down governance style creates opportunity for issues to be biased towards more popular and media-attractive groups.

\section{Avaaz and Social Legitimacy}

Although it was not possible in the scope of this research to interview Avaaz's stakeholders, there is reasonable evidence to cast a considerable shadow over the democratic quality of Avaaz's practices. Avaaz derives its legitimacy from its claim that it is member-funded and member-driven, acting on behalf of over 40 million individuals, but in the absence of documented member input (and considerable evidence that Avaaz follows its own agenda), and in the face of less transparent practices as revealed previously, this legitimacy is called into serious question.

For social legitimacy to be claimed, there would need to be proof that the people impacted by the decisions that are called into question have at a minimum been consulted and at best participated in the decision-making process. In previous sections it has already been established that decision-making is the exclusive purview of Avaaz's executive team, although campaign ideas are tested on samples of subscribers. Where there are consultations, these are closed-ended, one-way, and there is no direct link between member preferences and the issues Avaaz ultimately campaigns on. This is the same complaint that has exasperated promoters of meaningful public participation: even when citizens are consulted, there is no evidence their views had an impact on the final decisions. Avaaz has not improved these shortcomings of public participation. Only a few online advocacy organisations have in fact flirted with deeper participation, ${ }^{84}$ among them MoveOn, which soon decided to abandon the idea, 38 Degrees, which has experimented with two-step polls, and 350.org, which continues to experiment with training local organisers.

There is no information on how Avaaz obtains mandates to operate on behalf of citizens in remote countries, only an indication that they occasionally partner with other NGOs on the ground, and evidence that in some cases they take over local campaigns.

Avaaz may be creating its own legitimacy, by using the power of numbers, welltailored discourse and the speed the internet provides, to spread messages rapidly through online social networks before facts can be duly considered. Despite its rhetoric of "member-driven" actions, Avaaz clearly sees itself as leader of the revolt (see Responsiveness). The belief in a top-down approach is also patent in the Guardian interview, ${ }^{85}$ where campaign director Alice Jay actually dismisses grassroots activism as ineffective.

Lastly, Avaaz has shown that it is not afraid to meddle in foreign policy. It has been criticised for its militarist stance on Libya and Syria, ${ }^{86}$ and for interfering in

84. See, for example, Chadwick and Dennis, op. cit.

85. Ball, op. cit.

86. See, for example, John Hilary, "Internet Activists Should Be Careful What They Wish for in Libya", The Guardian, 10 March 2011, available: <http://www.theguardian.com/commentisfree/2011/mar/10/ internet-activists-libya-no-fly-zone> (accessed 15 June 2013). 
the sovereignty of Bolivia with an aggressive political campaign directed at the indigenous president Evo Morales. ${ }^{87}$

\section{Avaaz and Deliberation}

Deliberation as a tool to improve both the processes of decision-making as well as the quality of democratic practices has been well studied. Inspired by a republican virtue view of democracy, deliberation implies effective communication between all interested parties rather than bargaining or pooling interests. As shown in this article, Avaaz has no mechanism for discussion or debate with or among its members. Neither the issues and causes nor the campaigns or results, let alone the process leading to results, are up for discussion. There is no online forum, nor are there local or international meetings. Even though supporters can leave comments on Avaaz's social media sites, the design of these pages maintains the one-to-many communication form and permits Avaaz to highlight their own comments and eliminate supporters' comments, limiting the interaction to reaction. Kavada concluded earlier that Avaaz's communication model is strictly institutional, with member contributions managed so that they stay small, easy and frequent and all communication coordinated centrally by Avaaz. ${ }^{88}$ This control over communication and suppression of debate increases the risk of elite group bias and the polarisation of views.

This is another democratic deficit that is not exclusive to Avaaz, and relates to the balance between allowing supporters to grow and learn as activists and the need to mobilise large numbers in short periods of time. However, other advocacy organisations have experimented with ways to deepen participation, for example by creating local groups and offering them training and tools. More research might reveal how deliberation fares in these experiments.

\section{Avaaz and Reflexivity}

Reflexivity is an attitude of self-awareness that helps avoid the pitfalls of consensus and path dependency. In Avaaz's modus operandi, there are no indications of selfinquiry or self-confrontation. On the contrary, the numerous official replies to critics (even on relatively unknown blogs) tend to show a lack of humility and a defensive attitude. When Avaaz replies to critics, its spokespersons seem almost exasperated by the criticism and invariably justify Avaaz's actions circularly, by referring to its own actions. ${ }^{89} \mathrm{~A}$ case in point is their standard response to the accusation of promoting "clicktivism", 90 which returns the question, asking whether Gandhi could be accused of "walkavism" or Rosa Parks of "sitavism". The fact that Avaaz does not publish a record of its activities and only promotes its latest

87. Federico Fuentes, "Bolivia: NGOs Wrong on Morales and Amazon", Green Left Weekly (September 2011), available: <https://www.greenleft.org.au/node/48950> (accessed 16 June 2013). Avaaz's campaign: $<$ https://secure.avaaz.org/en/bolivia_stop_the_crackdown/?pv=31\&rc=fb> (accessed 16 June 2013).

88. Anastasia Kavada, "Collective Action and the Social Web: Comparing the Architecture of Avaaz.org and Openesf.net", in Communicative Approaches to Politics and Ethics in Europe: The Intellectual Work of the 2009 Ecrea European Media And Communication Doctoral Summer School (Tartu, Estonia: Tartu University Press, 2009), pp. 129-140.

89. Comment on John Hilary's article, "Internet Activists Should Be Careful What They Wish for in Libya", op. cit., available: <https://profile.theguardian.com/user/id/4501715> (accessed 15 June 2013).

90. Ball, op. cit. 
campaigns and a list of victories, with less successful campaigns disappearing from the site, emphasises its firm control over its discursive version of the global democracy exercise.

Avaaz winks at reflexivity through a small section on their site called Commitment to Accuracy, where it lists some of the "misrepresentations" they may have given, none of which are damaging. It would be useful to compare Avaaz's lack of reflexivity to that of similar organisations and of traditional NGOs and perhaps supranational agencies. Although Avaaz is particularly defensive, most organisations do not manage reflexivity well. After all, criticism and admissions of failure may damage the image of unity and competence the organisation has worked hard to build.

\section{Avaaz and Cognitive Justice}

For an organisation or group to practise cognitive justice, they need to allow for different views, like local and traditional knowledge, to be part of the debate on certain issues. Avaaz's one-to-many communication style, its formula for creating impact, which relies on exploring what they call "crisistunity" and on as many quantifiable factors as possible, their use of unnamed experts to justify claims, and the shallowness of the information provided for decision-making, point to an elite control over knowledge. Avaaz's core team and its advisors decide what knowledge is valid, how to frame the problems, solutions and priorities, and what version of facts to present. Avaaz's messages urge followers to act in seconds, long before the full message and implications have registered, basically offering two choices: to be on the side of the "good" or to shamefully let "bad" and "evil" walk the earth. ${ }^{91}$ All issues, even those exclusively involving foreign states, are presented through the Avaaz lens, with no voice given to local groups. Finally, Avaaz has no qualms about operating in foreign nations, with its own campaigners speaking to politicians and the media, and its adverts influencing public opinion.

\section{Conclusion}

The search for a global democracy model in a world coping with enormous social and environmental challenges, many of which are felt to be the result of global economic and political dynamics, has inspired a version of mass mobilisation via the internet. The organisations channelling these mobilisations went from unknown a decade ago to having become an unavoidable part of the changing political landscape. The sway that they hold over global public opinion and the place they have managed to command in traditional media, added to the speed at which they are growing their memberships, merits a closer look at their democratic claims.

In contrast to professional activist NGOs and grassroots movements, which usually develop in a specific location, rallying around a common cause and

91. Avaaz's ad for the 2012 Rio Summit was the object of criticism for its implicit racism: $<$ http://www. agriculturesnetwork.org/what-we-do/advocacy/rio-20/rio-20/friday-22-june-2012-rio-20-summit-finalday/image/image_view_fullscreen> (accessed 28 September 2016). 
growing country by country, forming new groups that identify with the cause, advocacy organisations like Avaaz are launched on the internet, grow their membership virtually and crowdsource their funding. They are unburdened by the internal politics of traditional movement development, having been thought up by a new breed of well-connected "movement development" professionals, and promoted as an instant global brand at almost zero marginal cost.

Despite their shallow version of participation, these organisations can be credited with exposing considerably more individuals to issues of human rights and other important social and ecological challenges. Avaaz has managed to create the largest ever virtual community, joining people from almost all countries in the world. Online movements should therefore not be dismissed out of hand. The weak ties that link people in and between networks have long been considered essential for broader mobilisation. These movements make up in speed and reach of communication what they lack in substance.

But there are some serious risks to democratic quality associated with this model of politics. The corporate branding style of framing issues may work to depoliticise mobilisation. Poignant issues run the risk of becoming the "meme" of the day, quickly forgotten as another issue takes its place. Multi-issue, menu-style activism may also destabilise the position and reputation of established NGOs and social movements, as well as potentially undermining local groups. As Gerbaudo warns, the populist and centralising tendencies of mass politics exclude minority views, masking the views of one group as that of all people ("we are the $99 \%$ "), a tendency he calls techno-plebiscitarianism. ${ }^{92} \mathrm{He}$ argues that this is reinforced by the existence of an invisible, and therefore unaccountable leadership that spurs supporters to vote on issues that have already been pre-decided. Finally, in his view, the ambition of online movements to build a new political process through social media is not matched by attempts to present substantive demands to improve social and economic conditions, thus reducing the whole direct democracy exercise to little more than "techno-proceduralism".

It is not easy to strike a balance between deep participation and large-scale mobilisation. Established NGOs struggle with this dilemma as much as the new digital movements, and both may be faulted for excluding other voices for the sake of a united voice. Democracy is often considered to be a process, and as such, it should not be the end, but the means with which to achieve goals of equity. For civil society organisations and movements to contribute meaningfully to the exercise of social and environmental justice, they need to develop the strong ties that help deepen knowledge, participation and social learning. This means they need to embrace democratic values such as transparency, responsibility and deliberation, in order to avoid the pitfalls of group bias, and improve their social legitimacy by empowering their members, allowing for more people to participate meaningfully in politics.

The analysis of Avaaz's practices revealed a failure to comply with what are considered basic democratic attributes. In particular, Avaaz showed a serious lack of transparency and accountability by not publishing information that would allow an assessment of their activities and by eliminating less successful campaigns from their site. There was also a marked lack of responsiveness to their members, even though as funders the latter may be considered de facto shareholders of the

92. Gerbaudo, op. cit. 
organisation. Evidence pointed to the possibility of dominant interest groups controlling the agenda at Avaaz, undermining guarantees of equality and freedom. Avaaz was also tested for deeper democratic attributes, where, unsurprisingly, it fared worse. The organisation provides no mechanism for deliberation, allowing members only to vote or react. The limited options for participation afforded to members and the dominance of particular interest groups may block minority views and interests, as well as limiting and polarising the issues campaigned on. The same restrictions also undermine Avaaz's main claim to legitimacy: that it speaks for its members, who are the real "bosses". By voting on pre-decided priorities, members are leaving Avaaz in firm control of the agenda, the message and the results.

Considering that there are alternative movements for participants who wish to engage more, are Avaaz's opaque practices a problem worth considering? The author argues that they are: the influence that Avaaz can exercise on public opinion, its capacity to infiltrate traditional media and the sheer numbers it places behind its messages, compounded by its financial resources and the fact that it does not shy away from interfering in foreign policy, all demands more scrutiny of its democratic practices. The Avaaz case revealed problematic democratic deficits in an organisation that has the attention of millions of internet users and that has built the capacity to rapidly infiltrate its message into the media and business sectors.

This research aimed to contribute to creating a model for critically assessing the democratic quality of the practices of political actors, focused in particular on, but not limited to, the organisations behind digital mass politics. Further research could refine the tools of the current, more exploratory assessment and look into different aspects of online public participation, such as the profile and motivations of the participants and to what extent certain democratic practices affect them, and the similarities or differences in democratic practices between traditional NGOs, digital NGOs and more spontaneous movements like Occupy.

\section{Acknowledgements}

I am very grateful to Britta Baumgarten and Nina Amelung for offering me the opportunity to deepen and refine my research into the democratic quality of online politics and public participation. Without their firm guidance and high quality standards, this article would never have lived up to its full potential. Thank you!

\section{Disclosure Statement}

No potential conflict of interest was reported by the author.

\section{Funding}

This work was supported by the Portuguese Science and Technology Fund (FCT) [grant SFRH/BD/80126/2011], awarded between January 2012 and December 2015 for the purpose of conducting PhD research. All work for environmental organisations is done on a voluntary basis. 


\begin{abstract}
About the Author
Lanka Horstink is completing her PhD in sociology on the topics of food politics and food democracy. Trained as a social psychologist and subsequently as a project manager, she has extensive experience in group dynamics both in forprofit and not-for-profit settings. After having managed communication teams and companies for more than a decade, in 2007 she started working with environmental NGOs, among them Greenpeace International and two Portuguese organisations, as a campaign manager, adult educator and community organiser. Her main interest is in the social-ecological dynamics of global politics, with an emphasis on the political economic factors that contribute to the democratic and ecological deficits that have been shown to persist.
\end{abstract}

